\title{
Noncanonical complexes of mammalian eEF1A with various deacylated tRNAs
}

\author{
P. V. Futernyk, B. S. Negrutskii, G. V. El'ska \\ Institute of molecular biology and genetics NAS of Ukraine \\ 150, Zabolotnogo Str, Kyiv Ukraine, 03680 \\ p.v.futernyk@imbg.org.ua
}

The formation of noncanonical complexes of two eEF1A isoforms with different types of deacylated tRNAs was examined and apparent dissociation constants were measured. A higher affinity to tRNA was found for the tissue specific isoform of elongation factor eEF1A2, as compared with that of eEF1A1. For the first time the formation of noncanonic complex of eEF1A with initiator $t R N A_{i}^{M e t}$ was found to be possible. A specific role of some tRNA sites in the interaction with eEF1A was discovered.

Keywords: translation, elongation factor $1 \mathrm{~A}$, channeling.

Introduction. Protein biosynthesis involves two general stages, namely the aminoacylation of tRNAs and mRNA translation on ribosomes. Translation is thought to be a very complex process, especially in higher eukaryotes. This process is characterized by a high level of structural and functional compartmentalization. Channeling is one of the mechanisms, explaining potential profit of compartmentalization in protein biosynthesis [1]. It was suggested that tRNAs are never free in the cytoplasm and all the time are bound to some partners like elongation factor $1 \mathrm{~A}$ (eEF1A), as eEF1A*GTP*aa-tRNA complexes, aminoacyl-tRNA synthetases (aaRS) or ribosomes [2]. According to the channeling conception there is a direct transfer of tRNA from E-site of ribosome to aaRS and aminoacyl-tRNA from aaRS to A-site of the ribosome without dissociation into cytoplasm [2]. Recently were have proposed that eEF1A may assist not only as a

(C) P. V. FUTERNYK, B. S. NEGRUTSKII, G. V. EL'SKA, 2008 carrier of aa-tRNA but also may execute a non-canonical function of the deacylated tRNA transfer from ribosome to aaRS in the form of eEF1A*GDP*tRNA ternary complex [3]. The existence of the latter in vitro has been shown by several techniques. Earlier we confirmed the formation of eEF1A*GDP*tRNA ${ }^{\text {Phe }}$ non-canonicalal ternary complex by fluorescence polarization method [4,5], and detected similar interaction for eEF1A1 and eEF1A2 with tRNA ${ }^{\text {Ser }}[6]$ by native gel band-shift assay. This means that the existence of such type of complexes may be a common feature of both eEF1A isoforms as well as different types of tRNA.

There are two isoforms, eEF1A1 and eEF1A2, of translation elongation factor in higher eukaryotes. eEF1A1 is present in almost all tissues except neurons and muscle cells. eEF1A2 functions only in neurons and muscles where it appears and replaces eEF1A1 during ontogenesis immediately after the birth of organism [7]. Until now any significant differences in functioning of these two isoforms were not found. 
In the present work we studied the formation of non-canonicalal complexes of eEF1A1 and eEF1A2 with tRNAs specific for Phe, Tyr, Asp, Leu, Ile, Met, Lys, and apparent dissociation constants $\left(\mathrm{K}_{\mathrm{d}}\right)$ were measured for each complex. Moreover, we first showed the possibility of non-canonical ternary complex formation between eEF1A1 or eEF1A2 and initiator tRNA ${ }_{i}^{\text {Met }}$. A role of specific base pairs in tRNA structure that influence its interaction with eEF1A was studied using a mutational analysis. We used in vitro transcribed tRNA ${ }_{3}^{\text {Lys }}$ with mutations in T-stem and acceptor stem for this purpose.

Materials and methods. Materials ATP; GDP; GTP, CTP, UTP, restrictase BshNI ("Fermentas" Lithuania), N,N-methilenbisacryamide; Tris; HEPES; Na-dodecylsulphate (SDS) ("Helicon" Russia); $\beta$-mercapthoetanol; Glycerol; $\mathrm{NH}_{4} \mathrm{Cl} ; \mathrm{MgCl}_{2}$ ("Merck" Germany); acrylamide (double recrystalised); TEMED; PMSF; DTT; EDTA ("Serva" Germany); Filters GF/C ("Whatman" Grate Britain); ammonium persulphate; Cumassi R-250 ("Bio-Rad" USA ); scintillation solution OptiPhase "HiSafe"("Sed" USA); GMP, phosphodiesterase of snake venom PDE I Type IV from Crotalus athrox venom, ("Sigma" USA); $\left[{ }^{32} \mathrm{P}-\alpha\right]$-ATP, [U- $\left.{ }^{14} \mathrm{C}\right]$-L-tyrosine, $\left[\mathrm{U}-{ }^{14} \mathrm{C}\right]-\mathrm{L}-$ phenylalanine, $\left[\mathrm{U}-{ }^{14} \mathrm{C}\right]$-L-leucine, $\left[\mathrm{U}-{ }^{14} \mathrm{C}\right]-\mathrm{L}$-isoleucine, [U- $\left.{ }^{14} \mathrm{C}\right]-\mathrm{L}$-aspartic acid, $\quad\left[\mathrm{U}-{ }^{14} \mathrm{C}\right]-\mathrm{L}-$ lysine, ("GE-Amersham" USA). [1- $\left.1{ }^{14} \mathrm{C}\right]$-L-methionine, $\left[1-{ }^{14} \mathrm{C}\right]$-L-proline ("Moravec Biocemicals" USA); T4-ligase, X-Gal, T4-polynucleotide kinase, restrictases BamHI, HindIII ("Roche" Germany), Qiagen Maxiprep Kit (“Qiagen” USA),

Other reagents were marked as "high grade" or "ultra pure".

T7 RNA-polymerase was a kind gift of Prof. M.A.Tukalo.

Nucleotide transferase was purified from yeasts as described in [8].

Total tRNA isolation. Total tRNA was obtained from bovine liver using direct deproteinization of tissue homogenate with phenol followed by chromatography on DEAE-cellulose [9]. Individual tRNA samples were isolated form total tRNA according to the procedure that includes chromatography on BD-cellulose and subsequent chromatographies on Spherogel-TSK DEAE 5PW, C3 RPSC 5u Ultrapore and Hypersil 5C4 ("Beckman") columns using HPLC Gold system. Initi- ator tRNA unlike elongator one may be aminoacylated by total aaRS from E.coli with $\left[{ }^{14} \mathrm{C}\right]$-methionine that was used for its detection. All individual tRNA samples

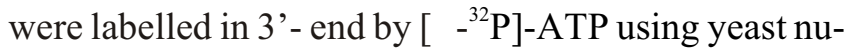
cleotide-tRNA transferase as described in [10].

eEF1A1 was purified from rabbit liver as described in [4], and eEF1A2 was purified from rabbit muscles by similar method, omitting only a gel filtration step.

Band retardation assay in poliacrylamide gel. The protein-RNA complex formation was studied by band retardation assay in polyacrylamide gel under native conditions. Incubation of elongation or initiation factors $(50-2000 \mathrm{nM}) 200 \mu \mathrm{M}$ GDP and $5000 \mathrm{cpm}$ of radioactively labelled tRNA was performed in $10 \mathrm{Fl} \mathrm{mix-}$ ture containing $20 \mathrm{mM}$ Tris- $\mathrm{HCl} \mathrm{pH}$ 7,5, $50 \mathrm{mM} \mathrm{KCl,} 5$ $\mathrm{mM} \mathrm{MgCl}, 2 \mathrm{mM}$ DTT and 10\% Glycerol. Incubation was done during $15 \mathrm{~min}$ at $37^{\circ} \mathrm{C}$, after that sample was loaded on native $5 \%$ polyacrylamide gel (acrylamide/N,N-methylenebisacrylamide ratio - 29/1) prepared in $25 \mathrm{mM}$ Tris/borate buffer $\mathrm{pH} 7.5$, containing $0.5 \mathrm{mM}$ EDTA and 5\% Glycerol. Electrophoresis was performed on minigel slabs during 2 hours at $4^{\circ} \mathrm{C}$ with $100 \mathrm{~V}$ constant voltage. Then gel was dried, exposed on ONIKO-RF1B (“AGFA") film for 18 hours at $+4 \mathrm{EC}$. The radio autographs obtained were analyzed with "GelProAnaliser" program.

$t R N A_{3}^{\text {Lys }}$ mutation in vitro. To develop the mutant $\mathrm{tRNA}_{3}{ }^{\text {Lys }}$ and control $\mathrm{tRNA}_{3}^{\text {Lys }}$ gene constructions we used the following oligonucleotides:

RS101 5'-AGC TTA ATA CGA CTC ACT-3';

RS111 5'-CTA TAG TGA GTC GTA TTA-3';

HK11 5'-ATA GCC CGG ATA GCT CAG TCG-3';

HK21 5'-GTA GAG CAT CAG ACT TT-3';

HK31 5'-TAA TCT GAG GGT CCA GGG TTC-3'; HK311 5'-TAA TCT GAG GGT CCG GGG TTC-3'; HK41 5'-AAG TCC CTG TTC GGG CGC CAG-3'; HK411 5'-AAG TCC CTG TCC GGG CGC CAG-3'; HK12 5'-CTA CCG ACT GAG CTA TCC GGG-3'; HK22 5'-GAT TAA AAG TCT GAT GCT-3'; HK32 5'-GAC TTG AAC CCT GGA CCC TCA-3'; HK321 5'-GAC TTG AAC CCC GGA CCC TCA-3'; HK413 5'-AAG TCC TTG TTC GGG CGC CAG-3'; 
HK422 5'-GAT CCT GGC GCC CGA ACA AG-3'; HK42 5'-GAT CCT GGC GCC CGA ACA GG-3'; HK421 5'-GAT CCT GGC GCC CGG ACA GG-3' (Synthesized by MWG-Biotech AG).

Oligonucleotides RS111, HK12, HK22, HK32, HK321 were phosphorilated by T4 polynucleotide kinase and, then, hybridized in pairs. The duplexes formed are shown below:

$$
\begin{aligned}
& \text { RS101 + RS11 = A; } \\
& \text { HK11 + HK12=B; } \\
& \text { HK21 + HK22=C; } \\
& \text { HK31 + HK32=D; } \\
& \text { HK311+ HK321=E; } \\
& \text { HK411+HK421=F; } \\
& \text { HK41 + HK42 = H; } \\
& \text { HK413+ HK422 = I, }
\end{aligned}
$$

These duplexes were mixed with pUC18 plasmid, restricted by BamHI and HindIII, in a manner shown in table 1 and ligated by T4 ligase.

XL-1-Blue competent cells were transformed by ligation mixtures as described in [11]. Positive clones were found after ampiciline and X-Gal selection.

Recombinant DNAs were isolated using Qiagen Maxiprep Kit. The sequence of each insert was confirmed using automatic sequenser ABI 377 ("Applied Biosystem", USA).

Preparative $T 7$ polymerase mediated synthesis of tRNA in vitro. The constructions obtained earlier were digested by BshNI that creates 3 'terminus of transcript lacking two last nucleotides $\mathrm{A}$ and $\mathrm{C}$ in tRNA sequence. Thus, the size of tRNA became 74 nucleotides instead of normal 76. In vitro transcription of tRNA was performed by T7-RNA polymerase in the mixture, containing $40 \mathrm{mM}$ TrisHCl $\mathrm{pH} 7,9,6 \mathrm{mM} \mathrm{MgCl}{ }_{2}, 10$ mM DTT, $10 \mathrm{mM} \mathrm{NaCl}, 2 \mathrm{mM}$ spermidine. ATP, GTP,

\footnotetext{
HindIII T7 promotor Coding sequence of tRNA $A_{3}^{L_{y s}}$

$5^{\prime}$ AagctTAATACGACTCACTATAGCCCGgatAGCTCAGTCGGTAGAGCATCA
}

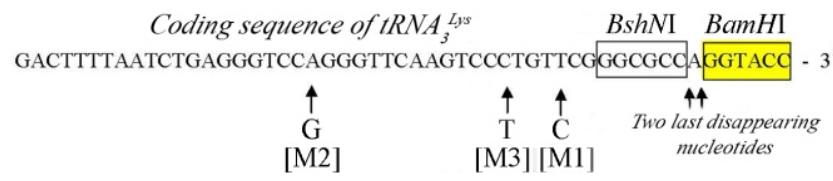

Construction of $\mathrm{tRNA}_{3}{ }^{\text {Lys }}$ gene cloned into $p U C 18$ plasmid.
Table 1.

Mutation variants of $t \mathrm{RNA}_{3}{ }^{\text {Lys }}$ gene.

\begin{tabular}{c|c|c|c}
\hline WT & M1 (U67:C67) & M2 (A50:G50) & M3 (C63:U63) \\
\hline A & A & A & A \\
B & B & B & B \\
C & C & C & C \\
D & D & E & D \\
H & F & H & I \\
\hline
\end{tabular}

CTP and UTP concentrations were adjusted corresponding to the ratio of each nucleotide present in the sequence. After synthesis being completed, the mixture was treated with DNAse I. Next. we purified transcribed tRNA by chromatography on DEAE cellulose (in buffer, containing $100 \mathrm{mM} \mathrm{NH}_{4} \mathrm{Ac}, 10 \mathrm{mM} \mathrm{MgCl}_{2}$, $100 \mathrm{mM} \mathrm{NaCl}$ ), and electrophoresis in $10 \%$ polyacrilamide gel (19:1) in the presence of $7 \mathrm{M}$ urea. A band, corresponding to the transcription product, was excised from gel and tRNA was extracted into water after overnight incubation on shaker at 37EC. Denaturation-renaturation of tRNA was done by heating till 72EC followed by slow cooling. Activity of each transcript was examined in aminoacylation reaction (data not shown). All transcripts were labelled by $\left[{ }^{32} \mathrm{P}\right] \mathrm{ATP}$ using yeast nucleotide-tRNA transferase as mentioned above.

Results.Comparison of the affinity of different tRNA species for eEF1A1 and eEF1A2. As mentioned earlier, tRNAs seem to be never free in a cell and all the time are bound to some partners - eEF1A, in the form of eEF1A*GDP*aa-tRNA complex, aaRSs or ribosomes. eEF1A was suggested to be a partner of deacylated tRNA, guiding it from the ribosome to aaRS during the tRNA channeling cycle [3]. We reported earlier the formation of ternary complex of eEF1A1*GDP with tRNA ${ }^{\text {Phe }}$ for which an apparent $\mathrm{K}_{\mathrm{d}}$ was measured by fluorescence polarization [4], whereas the dissociation constants for ternary complexes of eEF1A1*GDP and eEF1A2*GDP with tRNA $^{\text {Ser }}$ were estimated by band shift assay [6].

We studied the formation of non-canonical ternary complexes for GDP-bound form of eEF1A1 and eEF1A2 with tRNAs of different specificities, namely tRNA $^{\text {Asp }}$ (Fig. 1), tRNA ${ }^{\text {Ile }}$ (Fig. 2), tRNA ${ }^{\text {Tyr }}$, tRNA ${ }^{\text {Phe }}$, 
tRNA $^{\text {Met }}$, tRNA ${ }^{\text {Leu }}$, tRNA ${ }^{\text {Pro }}$ (Fig. 3), by the band retardation technique. The apparent $\mathrm{K}_{d}$ of protein-tRNA complexes was estimated to be equal to the concentration of eEF1A retaining a half of the labelled tRNA. The amount of free tRNA and bound with eEF1A was measured by densitometry. As shown in Figures 1-3, the $\mathrm{K}_{\mathrm{d}}$ values for eEF1A1*GDP complexes with tRNAs of various specificities are in 200-750 nM range, at the same time the $\mathrm{K}_{\mathrm{d}}$ for eEF1A2*GDP*tRNA complexes are in 50-400nM range. Interestingly, for all tRNAs studied the stability of eEF1A2*GDP*tRNA ternary complex is $2-4$ fold higher than that of the eEF1A1 mediated ternary complexes. Only one exception was observed for tRNA ${ }^{\text {Phe }}$ which has the same affinity for the both isoforms of elongation factor. All data for the ternary complexes formation are shown in table $2, K_{d}$ values were measured in this and previous studies $[4,6]$.

It is worth noting that $\mathrm{K}_{\mathrm{d}}$ value for the complex between eEF1A1 and tRNA ${ }^{\text {Phe }}$ presented here in table 2 differes considerably from the value obtained in the previous work. It is necessary to take into account that our results were obtained in non-equilibrium conditions in contrasr to the previous ones obtained at equilibrium by another method.

In this work we showed the formation of non-canonical complexes for eEF1A and 8 deacylated tRNAs of different specificities that is in favour of the deacylated tRNA channeling process. It is known that eEF1A binds all aminoacyl-tRNAs with a high and near equal affinity. The difference in $\mathrm{K}_{d}$ values observed for complexes between eEF1A isoforms and different deacylated tRNAs can be equalized by different impact of aminoacid residues resulting finally in similar stability of the eEF1A*GTP*aa-tRNA ternary complexes. Thus, the formation of eEF1A*GTP*aa-tRNA ternary complexes with equal thermodynamic characteristics may be important for their interactions with ribosome [12]. It was proposed, that such a mechanism of compensation exists for prokaryotic aa-tRNAs [13]. On the other hand, it was suggested that the primary structure of tRNA itself influences the interaction of respective aminoacyl-tRNA with prokaryotic elongation factor EF1A [14].

How can we explain the fact that two isoforms have different affinity for the same tRNA? There is no clear
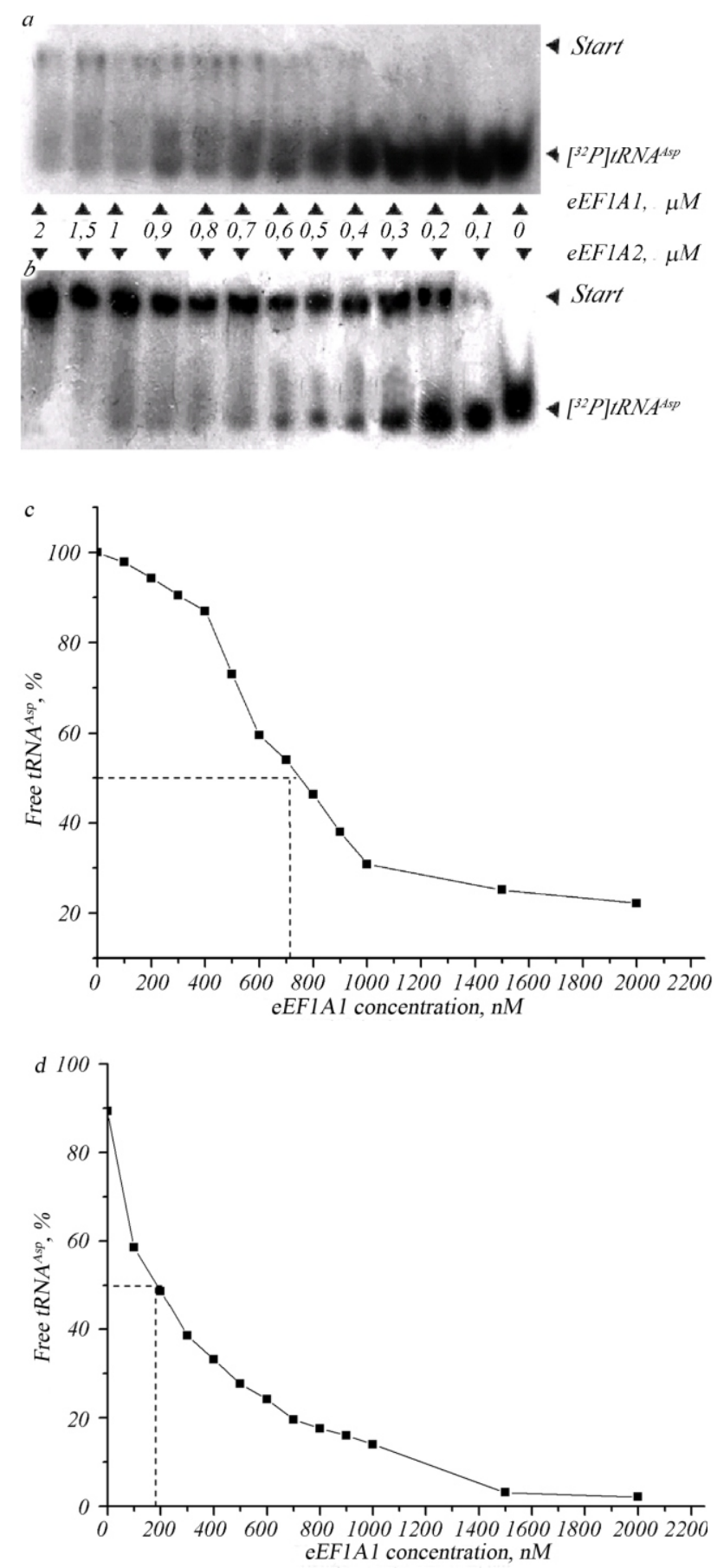

Fig. 1. Interaction of tRNA $^{\text {Asp }}$ with $\mathrm{eEF} 1 \mathrm{~A} 1 * \mathrm{GDP}$ and $\mathrm{eEF} 1 \mathrm{~A} 2 * \mathrm{GDP}$ visualized by band-shift assay in native PAGE. $a$ - autoradiography of free and complexed tRNA ${ }^{\text {Asp }}$, obtained at decreasing eEF1A1 concentrations ranging from $2 \mu \mathrm{M}$ to $0.1 \mu \mathrm{M} ; b$-densitometric analysis of the autoradiography with GelProAnalyser software. The curve reflects decreasing in free $\left[{ }^{32} \mathrm{P}\right]$ tRNA ${ }^{\text {ssp }}$ intensity as function of the eEF1A1*GDP concentration. The intensity of free $\left[{ }^{32} \mathrm{P}\right] \mathrm{tRNA}^{\text {Asp }}$ considered as $100 \% . c$ - autoradiography of free and complexed tRNA ${ }^{\text {Asp }}$ , obtained at decreasing eEF1A2 concentrations ranging from $2 \mu \mathrm{M}$ to $0.1 \mu \mathrm{M} ; d$ - the same as $c$ but for eEF1A2. 


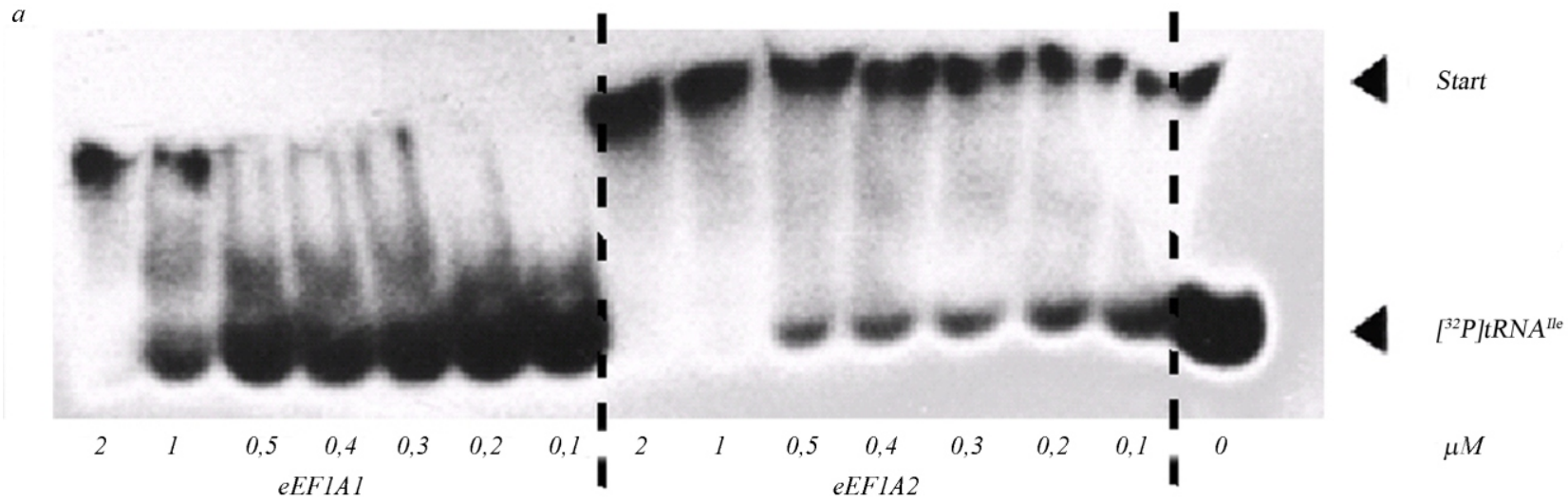

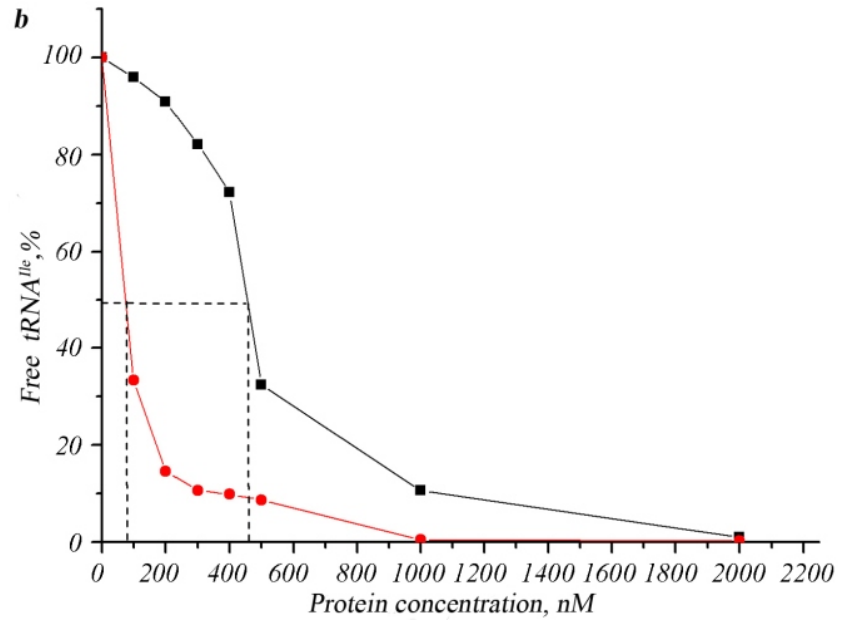

answer to this question. It was found that eEF1A1 has more extended conformation in solution than eEF1A2 [15], that, probably, may be a reason for such differences. Unfortunately, the results obtained allow us to suggest only the existence of some differences in functioning of two EF1A isoforms in the tissues where they are expressed.

For the fist time, we showed here the ability of two eEF1A isoforms to form the non-canonical ternary complexes with initiator tRNA ${ }_{i}^{\text {Met }}$ (Fig.4). According to Fig. 4 these complexes are formed having a similar stability as compared with the elongator tRNAs. Thus, $\mathrm{K}_{\mathrm{d}}$ for the complex eEF1A1*GDP* $\mathrm{tRNA}_{\mathrm{i}}{ }^{\text {Met }}$ is approximately $370 \mathrm{nM}$ and for the complex eEF1A2* $\mathrm{GDP}^{*} \mathrm{tRNA}_{\mathrm{i}}{ }^{\text {Met }}$ is $250 \mathrm{nM}$. The initiator tRNA interacts with both isoforms of elongation factor even better than some elongator tRNA, including tRNA $\mathrm{e}_{\mathrm{e}}^{\text {Met }}$. The formation of non-canonical complexes of eEF1A with the initiator tRNA was neither expected nor predicted [16]. Moreover, it was shown that Met-tRNA ${ }_{i}^{\text {Met }}$
Fig. 2. Interaction of tRNA ${ }^{\text {Ile }}$ with eEF $1 \mathrm{~A} 1 * \mathrm{GDP}$ and $\mathrm{eEF} 1 \mathrm{~A} 2 * \mathrm{GDP}$ visualized by band-shift assay in native PAGE. $a$-Autoradiography of free and complexed tRNAI ${ }^{\mathrm{le}}$, obtained at decreasing eEF1A1(left part) or eEF1A2 (right part) concentrations ranging from $2 \mu \mathrm{M}$ to $0.1 \mu \mathrm{M}$ (with smaller increment than in Fig.1). $b$ - Densitometric analysis of the autoradiography with GelProAnalyser software. The curve reflects decreasing in free $\left[{ }^{32} \mathrm{P}\right] \mathrm{tRNA}{ }^{\text {Ile }}$ intensity as function of the eEF $1 \mathrm{~A}$ GDP concentration. The intensity of free $\left[{ }^{32} \mathrm{P}\right] \mathrm{tRNA}^{\mathrm{Ile}}$ considered as $100 \%$.

did not act as an elongator tRNA in a cell-free protein synthesis system. Besides, tRNA $_{\mathrm{i}}^{\text {Met }}$ has two antideterminants for eEF1A: one is the acceptor stem base pair - A1:U72, second, the T-stem base pairs A50:U64 and U51:A63 [17]. On the other hand, Met-tRNA $_{i}^{\text {Met }}$ of plants and yeasts has A64-phosphoribosilation as another antideterminant [18]. Probably, the interaction between eEF1A and Met-tRNA ${ }_{i}^{\text {Met }}$ does not take place because of the absence of contact between protein and aminoacid residue (which is oriented in elongator Met-tRNA $\mathrm{e}^{\mathrm{Met}}$ at another angle relatively to the acceptor stem). We suppose, that the pair U51:A63 in T-stem of tRNA ${ }_{i}^{\text {Met }}$ is not strong enough as an antideterminant for the elongation factor, that may be a possible explanation for the existence of non-canonical eEF1A* GDP* $\mathrm{tRNA}_{\mathrm{i}}^{\mathrm{Met}}$ complex.

We believe that formation of the eEF1A1/eEF1A2*GDP*tRNA ${ }_{i}^{\text {Met }}$ complex could be important for the eEF1A mediated channeling of initiator tRNA after its release from the E-site of ribosome 
$a$
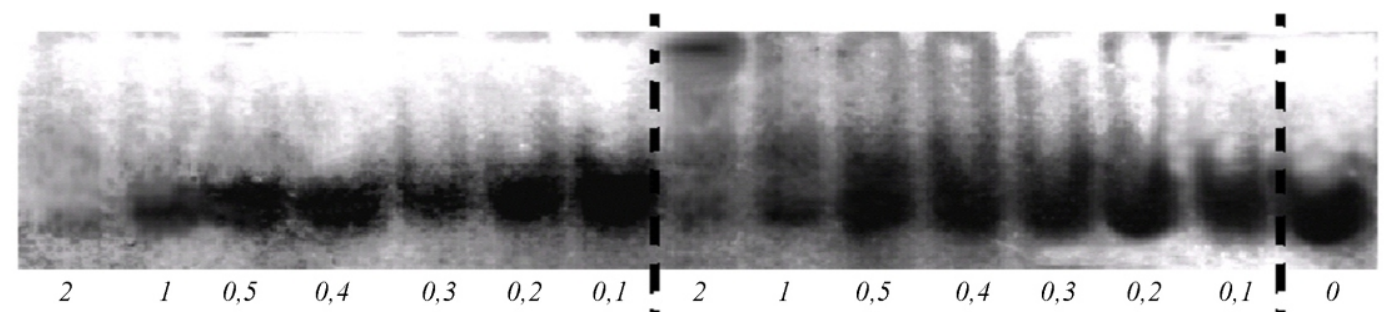

Start eEF1A1
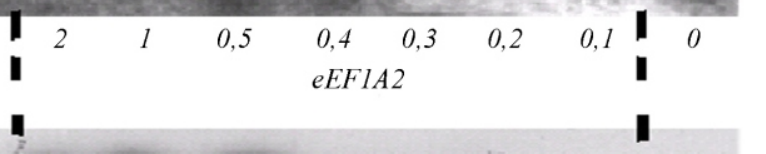

$\left[{ }^{32} P\right] t R N A^{T y r}$

$\mu M$

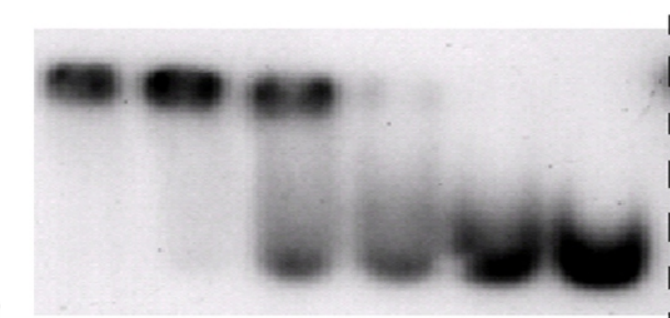

b
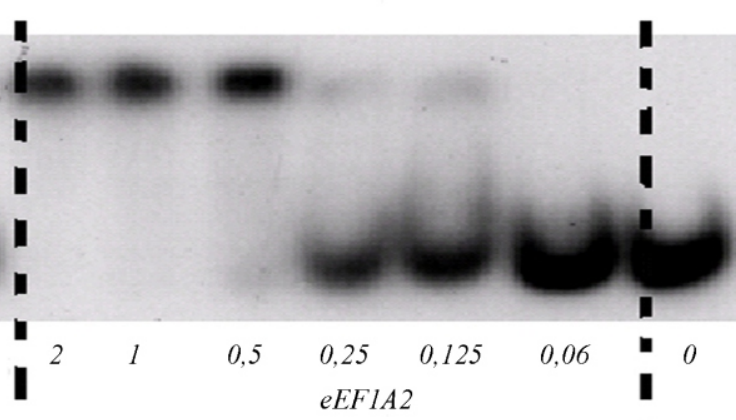

1 Start
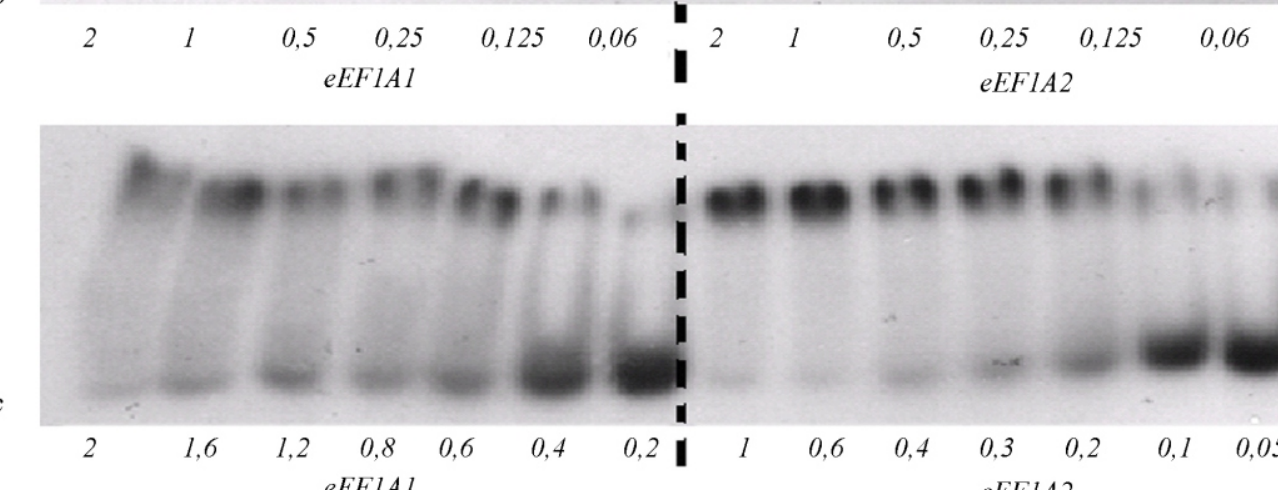

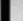

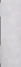
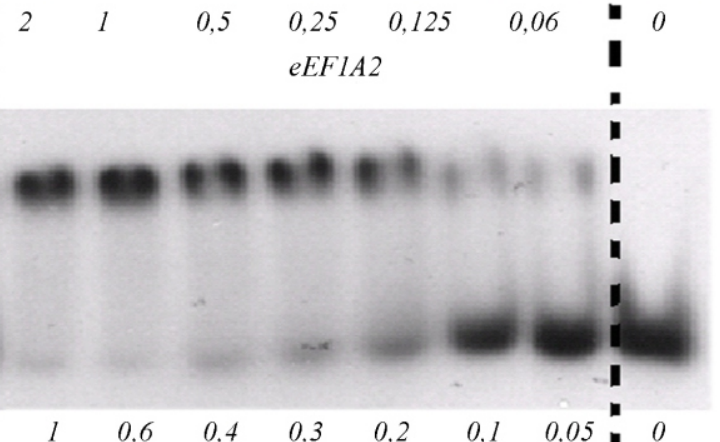

$\mu M$

$\left[{ }^{32} P\right] t R N A^{\text {Phe }}$

Start

$\left.{ }^{32} \mathrm{P}\right] \mathrm{tRN} A^{\mathrm{Leu}}$

$\mu M$
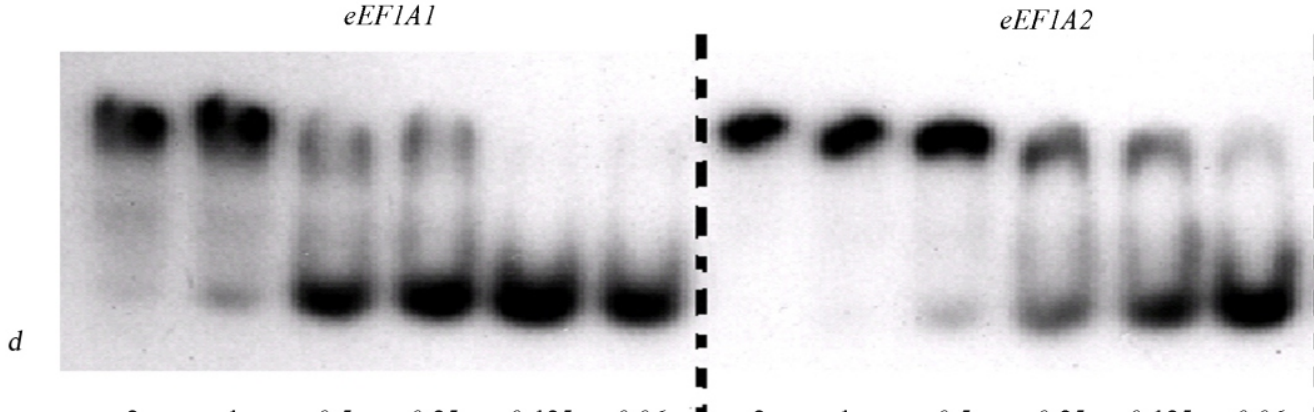

eEF $1 A 2$
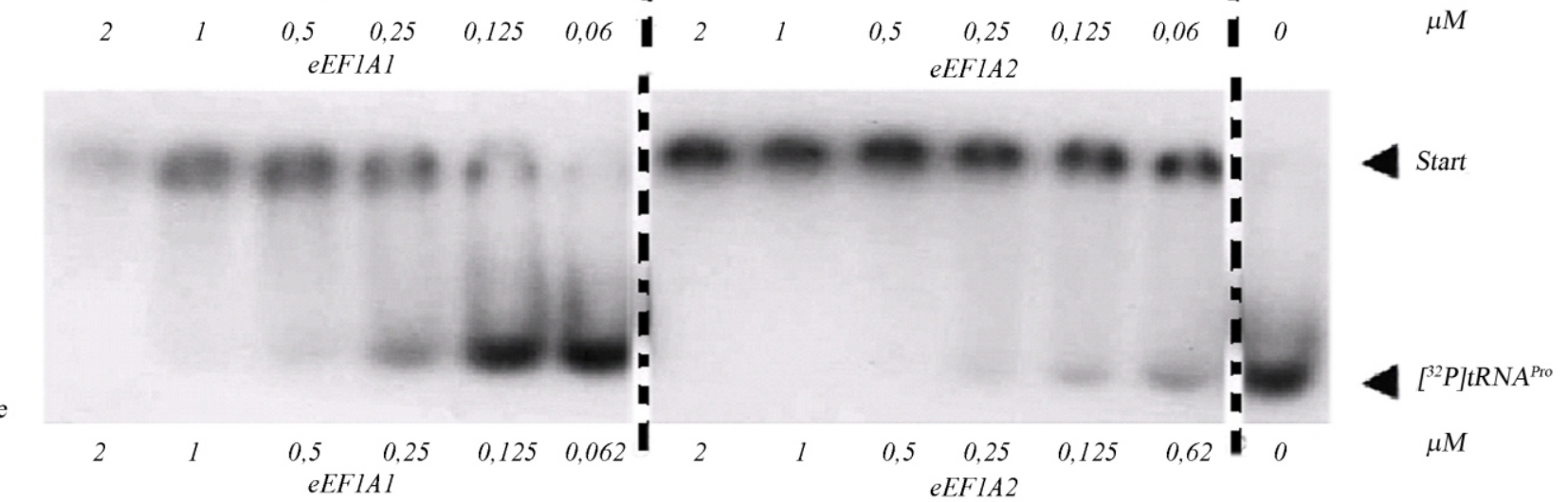

Fig. 3. Interaction of eEF1A1*GDP or eEF1A2*GDP with various elongator tRNAs. Autoradiography for: $a-\mathrm{tRNA}^{\mathrm{Tyr}}, b-\mathrm{tRNA}^{\mathrm{Phe}}, c-\mathrm{tRNA}{ }_{\mathrm{e}}^{\mathrm{Met}}, d-\mathrm{tRNA}^{\mathrm{Leu}}, \mathrm{E}-\mathrm{tRNA}{ }^{\text {Pro }}$. 
Table 2.

The affinity of eEF1A isoforms to various tRNAs.

\begin{tabular}{c|c|c}
\hline \multirow{2}{*}{ tRNA } & \multicolumn{2}{|c}{$K_{\mathrm{d}}, \mathrm{nM}$} \\
\cline { 2 - 3 } & eEF1A1 & eEF1A2 \\
\hline Pro & 200 & 50 \\
Phe & 250 & 250 \\
Phe & $9 *$ & - \\
Tyr & 750 & 400 \\
Ile & 470 & 100 \\
Met & 700 & 300 \\
Leu & 600 & 150 \\
Ser & $350 *$ & $120 *$ \\
Asp & 750 & 250 \\
Met & 370 & 250 \\
\hline
\end{tabular}

The values obtained in the previous studies are marked with asterisk $\left(^{*}\right)[3,5]$.

Table 3.

Disosiation constant for the complexes of translation initiation and elongation factors with initiator or elongator $t R N A^{\text {Met }}$

\begin{tabular}{c|c|c|c}
\hline \multirow{2}{*}{ Комплекс } & \multicolumn{3}{|c}{$\mathrm{K}_{\mathrm{d}}, \mathrm{nM}$} \\
\cline { 2 - 4 } & $\mathrm{tRNA}_{\mathrm{e}}{ }^{\mathrm{Met}}$ & $\mathrm{tRNA}_{\mathrm{i}}{ }^{\mathrm{Met}}$ & $\mathrm{tRNA}^{\text {Leu }}$ \\
\hline $\mathrm{eIF} 2 * \mathrm{GDP}$ & 100 & 160 & $>1500$ \\
$\mathrm{eEF} 1 \mathrm{~A} 1 * \mathrm{GDP}$ & 600 & 370 & 600 \\
$\mathrm{eEF} 1 \mathrm{~A} 2 * \mathrm{GDP}$ & 250 & 250 & 150 \\
\hline
\end{tabular}

to methionyl-tRNA synthetase. Besides, the ability of eIF2, $\gamma$-subunit of which is homologous to eEF1A, to interact with deacylated tRNA ${ }_{i}^{\text {Met }}$ and $\mathrm{tRNA}_{\mathrm{e}}{ }^{\text {Met }}$ but not with other elongator tRNAs [19] may be considered as an alternative possibility for the initiator tRNA channeling. The comparison of $\mathrm{K}_{\mathrm{d}}$ values for the eIF2 complexes is shown in Table 3 together with the corresponding values for eEF1A1 and eEF1A2. As can be seen, $\mathrm{K}_{\mathrm{d}}$ values for the eEF1A non-canonical ternary complexes are much higher than $\mathrm{K}_{\mathrm{d}}$ values for respective eIF2*GDP complexes, but we believe that this does not prevent eEF1A from interaction with all deacylated tRNAs in order to deliver them to aaRSs. Thus, all the results obtained are in favour of the tRNAs channeling during translation at the elongation and initiation steps.

Determination of the $G$ :U base pair significance in 51:63 and 50:64 positions of tRNA for its interaction with eEF1A. The sites responsible for interaction with tRNA have been found recently in prokaryotic EF1A [13]. It was also found that $\mathrm{G}: \mathrm{C}$ base pair is more often present at 51:63 position of tRNA than A:U base pair. Among mammals only tRNA ${ }_{(\mathrm{QUU})}{ }^{\mathrm{Asn}}$, $\mathrm{tRNA}_{(\mathrm{UGA})}{ }^{\text {Ser }}$ and $\operatorname{tRNA}_{i}{ }^{\text {Met }}$ have $A: U$ base pairs at $51: 63$ position, and tRNA $^{\text {Phe }}$ and tRNA ${ }^{\text {Tyr }}$ have G:U.

We studied the importance of these positions in tRNA structure for the interaction with eEF1A. The $\mathrm{tRNA}_{3}{ }^{\mathrm{Lys}}$ in vitro mutagenesis was described in Methods. Mutant and control tRNAs had comparable activity in aminoacylation test (data not shown). We studied the affinity of mutant tRNAs for both isoforms of eEF1A by band retardation assay (Fig. 5). The results

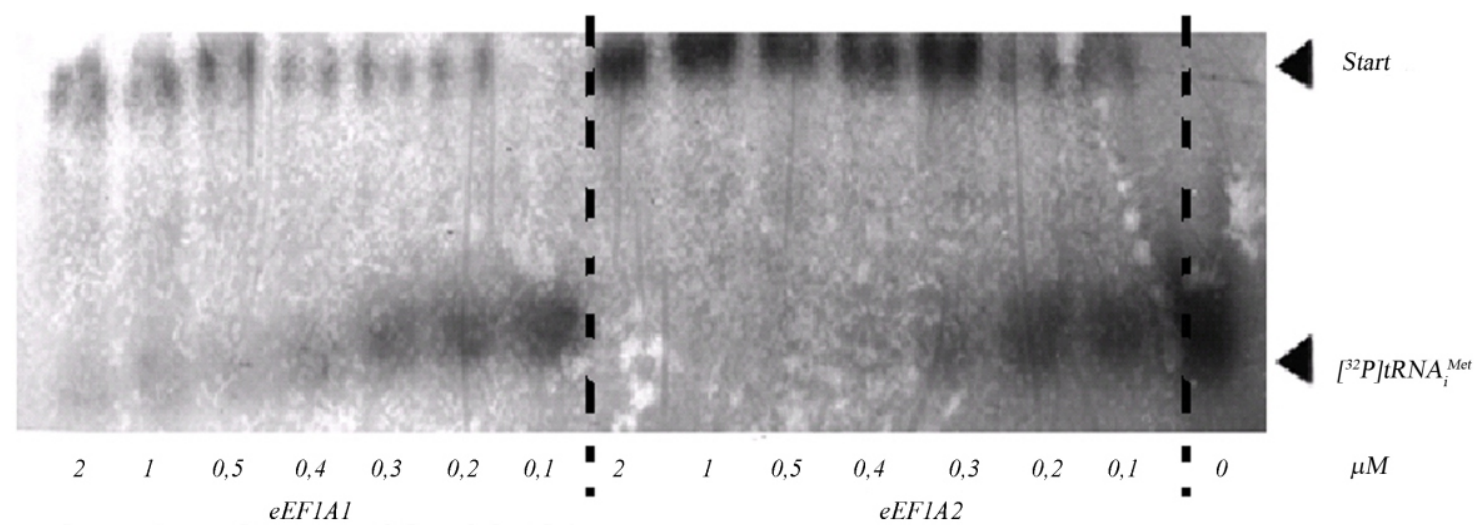

Fig. 4. Interaction of tRNA ${ }_{i}^{\text {Met }}$ with GDP-bound forms of eEF1A and eEF1A2. Autoradiography of native gels 


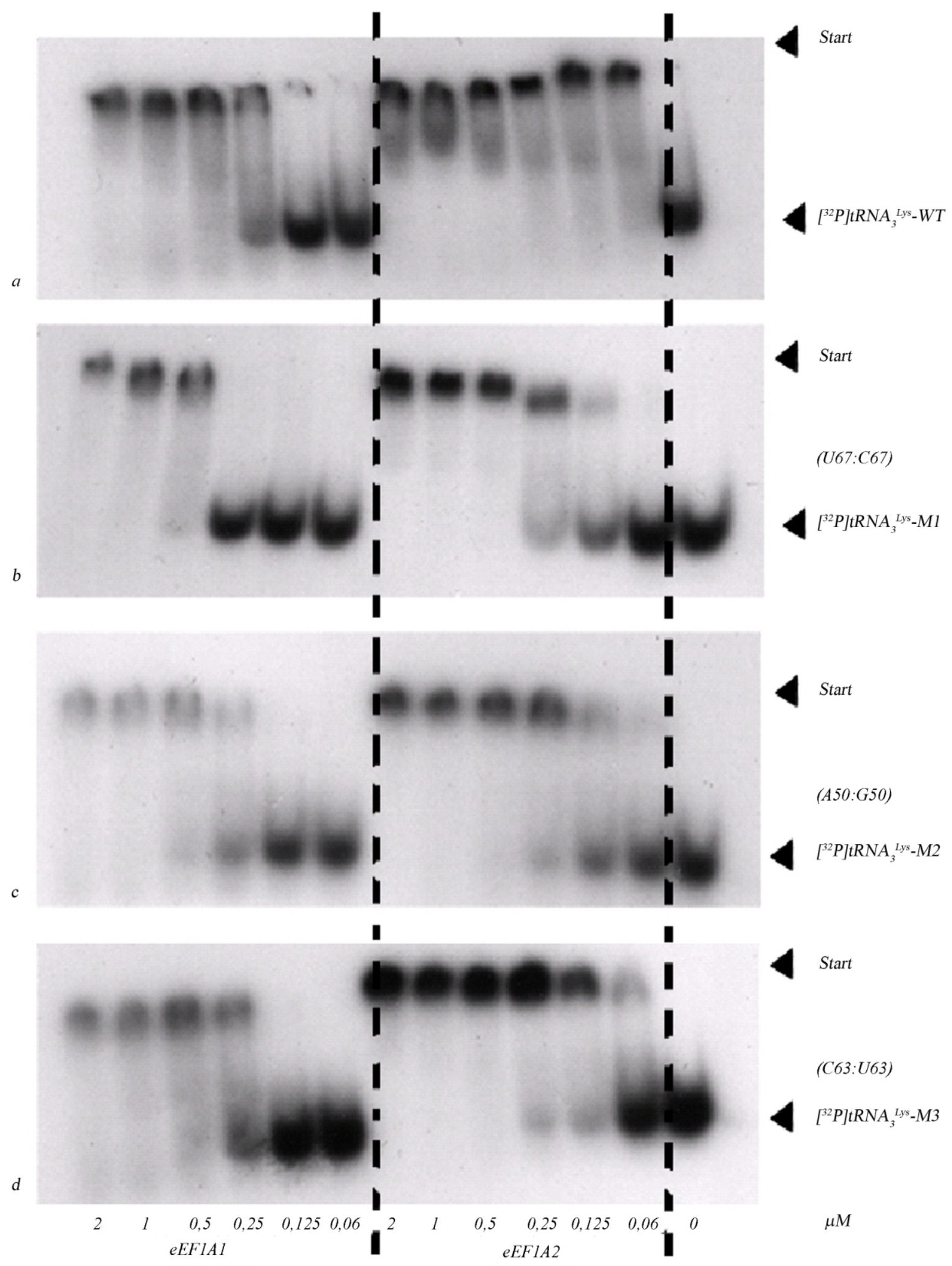

Fig. 5. Interaction of wild type and mutant $\mathrm{RNAA}_{3}{ }^{\text {Lys }}$ with eEF1A $1 * \mathrm{GDP}$ and eEF1A2*GDP. Autoradiography $a-\mathrm{tRNA}_{3}{ }^{\text {Lys }} \mathrm{WT}, b-\mathrm{tRNA}_{3}{ }^{\mathrm{Lys}} \mathrm{M} 1, c-\mathrm{tRNA}_{3}{ }^{\mathrm{Lys}} \mathrm{M} 2, d-\mathrm{tRNA}_{3}{ }^{\text {Lys }} \mathrm{M}_{3}$ 
Table 4

The affinity of normal and mutant $t R N A_{3}{ }^{\text {Lys }}$ for two eEF $1 \mathrm{~A}$ isoforms.

\begin{tabular}{c|c|c}
\hline \multirow{2}{*}{ tRNA } & \multicolumn{2}{|c}{$K_{\mathrm{d}}, \mathrm{nM}$} \\
\cline { 2 - 3 } & eEF1A1 & eEF1A2 \\
\hline LysWT & 250 & 30 \\
LysM1 (U67:C67) & 330 & 120 \\
LysM2 (A50:G50) & 400 & 170 \\
LysM3 (C63:U63) & 250 & 100 \\
\hline
\end{tabular}

revealed only slight impact of the G:U base pair presence in tRNA on interaction with eEF1A1. The insertion of $\mathrm{G}: \mathrm{U}$ base pairs at 51:63 position did not change $\mathrm{K}_{\mathrm{d}}$ values, but G:U at 50:64 position increased $\mathrm{K}_{\mathrm{d}}$ values from $250 \mathrm{nM}$ to $400 \mathrm{nM}$ i.e. less than 2 fold. For the eEF1A2 complex the presence of G50:U64 base pair increased $\mathrm{K}_{\mathrm{d}}$ from $30 \mathrm{nM}$ to $170 \mathrm{nM}$, and G51:U63 to $100 \mathrm{nM}$, i.e. 5,5 and 3 fold respectively.

Thus, we found that positions 51:63 and 50:64 in the elongator $\mathrm{RRNA}_{3}^{\text {Lys }}$ are important for tRNA interaction with eEF1A. We detected even higher impact of these mutations on interaction with eEF1A2, when the affinity of tRNA decreased about 5 fold even if A50:U64 changed to more favourable G50:U64 base pair, and 3 fold if G51:C63 changed to G51:U63. Data are shown in Table 4.

The differences found for the $K_{d}$ values of ternary complexes for various mutant and wild type tRNAs as well as different affinity of one tested tRNA for two isoforms of eEF1A demonstrate that both protein and tRNA contribute to the interaction.

Thus, we found that formation of non-canonical ternary complexes of tRNA with eEF1A*GDP is universal, and seems to be an intrinsic feature of all elongator tRNAs. These complexes are inherent for both isoforms of eEF1A. We also observed the non-canonical ternary complexes of initiator tRNA with both isoforms of eEF1A. Surprisingly, eEF1A2 forms such complexes with higher affinity than eEF1A1 to almost all examined deacylated tRNAs. We also studied the structure elements of tRNA responsible for eEF1A binding and found that replacement of G64:C50 base pairs for G64:U50 and C63:G50 for U63:G50 in $\mathrm{T}$-stem results in valuable decrease in $\mathrm{tRNA}_{3}{ }^{\text {Lys }}$ affinity to both isoforms of eEF1A. This proves an essential role of the mentioned positions in the formation of non-canonical complex tRNA*eEF1A*GDP .

We thank Novosylna O.V. for the help in purification of elongation factors.

This work was partly supported by the Program of joint projects of NAS Ukraine and Russian Foundation for Basic Research 2008-2009. (Agreement 21).

\section{П. В. Футерник, Б. С. Негруиький, Г. В. Сльська}

Неканонічні комплекси еEF1 А ссавців з деацильованими тРНК різної специфічності

Резюме

Розглянуто формування неканонічних комплексів двох ізоформ еукаріотного фактора елонгачіі еEF1A з деацильованими тРНК різних спеичфічностей та виміряно уявні константи дисоціації. Виявлено більшу спорідненість до тРНК тканиноспецифічної ізоформи фактора елонгації еЕF1A2 порівняно з еЕF1A1. Вперше показано принципову можливість утворення неканонічних комплексів еEFIA з ініціаторною mPHК Меt. Визначено роль окремих сайтів $y$ структурі тРНК, відповідальних за взаємодію з eEF1A.

Ключові слова: транслячія, фактор елонгачіï, каналювання.

\section{П. В. Футерник, Б. С. Негруиякий, А. В. Ельская}

Неканонические комплексы eEF1A млекопитающих с деацилированными тРНК разной специфичности

Резюме

Рассмотрено формирование неканонических комплексов двух изоформ фактора элонгации еEFIA с деацилированными тРНК разных специфичностей и измерены кажущиеся константы диссоциации. Выявлено большее сродство к тканеспециффической изоформы фактора элонгации еЕF1A2 по сравнению с еЕF1A1. Впервые показана принципиальная возможность образования неканонических комплексов еEF1A c инициаторной $\mathrm{mPHK}_{i}^{\text {Mеt}}$. Определена роль отдельных сайтов в структуре тРНК, ответственных за взаимодействие $c$ eEF1A.

Ключевые слова: трансляция, фактор элонгаџии 1A, каналирование. 


\section{REFERENCES}

1. Ryazanov, A. G., Ovchinnikov, L. P., Spirin, A. S. Development of structural organization of protein- synthesizing machinery from prokaryotes to eukaryotes // Biosystems.-1987.-20.-P. 275-288.

2. Negrutskii B. S., Deutscher M. P. Channeling of aminoacyltRNA for protein synthesis in vivo // Proc. Nat. Acad. Sci. USA.-1991.-88.-P. 4991-4995.

3. Negrutskii B. S., El'skaya A. V. Eukaryotic translation elongation factor 1A: structure, expression, functions, and possible role in aminoacyl-tRNA channeling // Progr. Nucl. Acid Res. Mol. Biol.-1998.-60.-P. 48-77.

4. Petrushenko Z. M., Negrutskii B. S., Ladokhin A. S., Budkevich T. V., Shalak V. F., El skaya A. V. Evidence for the formation of an unusual ternary complex of rabbit liver EF-1 $\alpha$ with GDP and deacylated tRNA // FEBS Lett.-1997.- 407.P. 13-17.

5. Petrushenko Z. M., Budkevich T. V., Shalak V. F., Negrutskii $B$. S., El'skaya $A$. $V$. Novel complexes of mammalian translation elongation factor eEF1A*GDP with uncharged tRNA and aminoacyl-tRNA synthetase. Implications for tRNA channeling // Eur. J. Biochem.-2002.-269.-P. 48114818.

6. Футерник П. В., Погрібна А. П., Петрушенко 3. М., Негруиький Б. С., Сльська Г. В. Дослідження комплексів фактора елонгації 1 А 3 тРНК ${ }^{\text {Сер }}$ та серил-тРНК синтетазою // Біополімери і клітина.-2004.-20, № 1-2.-С. 17-23.

7. Newbery H. J., Loh D. H., O'Donoghue J. E., Tomlinson V. A. L., Chau Y.-Y., Boyd J. A., Bergmann J. H., Brownstein D., Abbott C. M. Translation elongation factor eEF1A2 is essential for post-weaning survival in mice // J. Biol. Chem.2007.-282.-P. 28951-28959.

8. Sternbach H., von der Haar F., Schlimme E., Gaertner E., Cramer F. Isolation and properties of tRNA nucleotidyl transferase from yeast // Eur. J. Biochem.-1971.-22.-P. 166172.

9. Brungraber E. F. A simplified procedure for the preparation of «soluble» RNA from rat liver // Biochem. and Biophys. Res. Communs.-1962.-8.-P. 1-3.

10. Silberclang M., Gillum A. M., RajBhandary U. L. Use of in vitro ${ }^{32} \mathrm{P}$ labeling in the sequence analysis of nonradioactive tRNAs // Meth. Enzymol.-1979.-59.-P. 58-109.
11. Maniatis T., Fritsch E. F., SambrookJ. Molecular cloning: a laboratory manual.-New York: Cold Spring Harbor Lab. press, 1989.

12. Louie A., Ribeiro S. N., Reid B. R., Jurnak F. Relative affinities of all Escherichia coli aminoacyl-tRNAs for elongation factor Tu-GTP // J. Biol. Chem.-1984.-259.P. 5010-5016.

13. LaRiviere F. J., Wolfson A. D., Uhlenbeck O. C. Uniform binding of amynoacyl-tRNAs to elongation factor Tu by thermodynamic compensation // Science.-2001.-294.P. 165-168.

14. Sanderson L. E., Uhlenbeck $O$. C. The 51-63 pair of tRNA confers specificity for binding by EF-Tu // RNA.-2007.-13.P. 835-840.

15. Budkevich T. V., Timchenko A. A., Tiktopulo E. I., Negrutskii B. S., Shalak V. F., Petrushenko Z. M., Aksenov V. L., Willumeit R., Kohlbrecher J., Serdyuk I. N., El'skaya A. V. Extended conformation of mammalian translation elongation factor $1 \mathrm{~A}$ in solution // Biochemistry.-2002.-41.-P. 53425349.

16. Stortchevoi A., Varshney U., RajBhandary U. L. Common location of determinants in initiator transfer RNAs for initiator-elongator discrimination in bacteria and in eukaryotes // J. Biol. Chem.-2003.-278.-P. 17672-17679.

17. Drabkin H. J., Estrella M., RajBhandary U. L. Initiatorelongator discrimination in vertebrate tRNAs for protein synthesis // Mol. and Cell. Biol.-1998.-18.-P. 1459-1466.

18. Kiesewetter S., Ott G., Sprinzl M. The role of modified purine 64 in initiator/elongator discrimination of $\mathrm{tRNA}_{\mathrm{i}}{ }^{\mathrm{Met}}$ from yeast and wheat germ // Nucl. Acids Res.-1990.-18.P. 4677-4682.

19. Футерник П. В., Негруиьький Б. С., Сльська Г. В. Формування неканонічних комплексів тPHК Мет та тPHК Мет 3 фактором ініціації 2 ссавців / Наук. вісн. Чернів. ун-ту: 3б. наук. праць (Біологія).-Чернівці: Рута, 2006.Вип. 297.-С. 3-7. 